\title{
Quantitative evidence for spatial variation in the biennial life cycle of the mountain butterfly Erebia euryale (Lepidoptera: Nymphalidae) in the Czech Republic
}

\author{
Irena KLECKOVA ${ }^{1,2}$, PAVEl VRBA ${ }^{1}$ and Martin KONVICKA ${ }^{1,2, *}$ \\ ${ }^{1}$ Faculty of Science, University of South Bohemia, Branisovska 1760, 37005 Ceske Budejovice, Czech Republic; \\ e-mails: konva333@gmail.com; irena.slamova@gmail.com; vrba_pavel@centrum.cz \\ ${ }^{2}$ Biology Centre of the Academy of Sciences of the Czech Republic, v.v. i., Institute of Entomology, Branisovska 1160/31, \\ 37005 Ceske Budejovice, Czech Republic
}

Key words. Lepidoptera, Nymphalidae, Erebia euryale, butterfly ecology, Central Europe, monitoring, mountain forests, phenology, life cycle, voltinism

\begin{abstract}
Erebia euryale (Esper, 1805) is a montane-zone representative of a Holarctic butterfly genus the species of which occur mainly in alpine areas. As in many mountain insects, E. euryale frequently undergoes a prolonged biennial larval development, which can be synchronised across mountains, resulting in prominent biennial peaks in adult emergence. However, the extant reports are often contradictory, suggesting that populations are not synchronized. We present the first quantitative assessment of the situation in the Czech Republic, based on five years of monitoring adults along transects in three major mountain systems in this country. We detected a two order magnitude difference in biennial fluctuations in adult abundance, with peaks in even years (i.e. 2010, 2012) in the Šumava Mts (southwest Czech Republic). There were less distinct odd year (i.e. 2009, 2011, 2013) peaks in the Hrubý Jeseník Mts (northeast) and no fluctuations from year to year in the number of adults recorded in the Krkonoše Mts (north). Although the mechanisms behind these patterns remain unknown, we hypothesize that rugged terrain desynchronises and flat terrain synchronises the length of development of E. euryale. Finally, the different periodicity in the fluctuations in individual mountain ranges is hypothesized to be affected by interactions with larval parasitoids or reflect the different postglacial histories of respective populations.
\end{abstract}

\section{INTRODUCTION}

Prolonged development, spanning more than one growing season, is a well known phenomenon in insects living in harsh and cold environments in the high Arctic (e.g. Kukal \& Kevan, 1987; Mikkola \& Kononenko, 1989) or high mountains (e.g. Wipking \& Mengelkoch, 1994). In addition, to the need to prolong development in shortseason environments, this has been attributed to parasitism by parasitoids (Varkonyi et al., 2002), host plant defences (Dennis et al., 2004), predator saturation (Gilg et al., 2006) or weather catastrophes such as several long winters (Valle, 1933). A genetic background for biennial development has also been sought (Douwes \& Stille, 1988; Vila \& Bjorklund, 2004). Answering the general ecological question: What is the effect of regional climate vs. population history on length of development? - is difficult, as it is obscured by a paucity of robust quantitative data, even for otherwise well-studied European butterflies (Settele et al., 2009).

The butterfly genus Erebia Dalman, 1816 (Lepidoptera: Nymphalidae: Satyrinae) is notable for its radiation in northern temperate cold regions, mainly in the mountains, and is increasingly used as a model insect for studying mountain biogeography and ecology (e.g., Konvicka et al., 2002; Cizek et al., 2003; Schmitt et al., 2006; Schmitt \&
Haubrich, 2008; Vrba et al., 2012). Biennial development, resulting in much higher adult numbers in alternate years, is a common feature of this genus (Warren, 1936). To date, the most reliable information on the development of Erebia originates from studies carried out over several years, mainly in the Alps (Wipking \& Mengelkoch, 1994; Sonderegger, 2005) and the Arctic (Douwes, 1980; Douwes \& Stille, 1988). These authors agree that biennial development occurs in some species and there are regional variations in the pattern. The records of adult abundance obtained from museum collections or field observations can be biased. For instance, Erebia "poor seasons" could be part of entomology folklore, making it difficult to separate an existing biennial pattern from a biennial bias in visits to the mountains. In addition, captive breeding reports, which often document single-year development, may reflect more favourable breeding conditions (Roos \& Arnscheid, 1981; Sonderegger, 2005).

This contribution, based on observations carried out over a period of five-years along transect in three mountain areas in the Czech Republic, presents quantitative evidence of biennial fluctuations in the adult abundance of the butterfly Erebia euryale (Esper, 1805). This butterfly inhabits open woodlands and clearings in the montane zone of European mountains (Kudrna et al., 2011), where the conditions are less harsh than those experienced by the majority of its al-

\footnotetext{
* Corresponding author.
} 


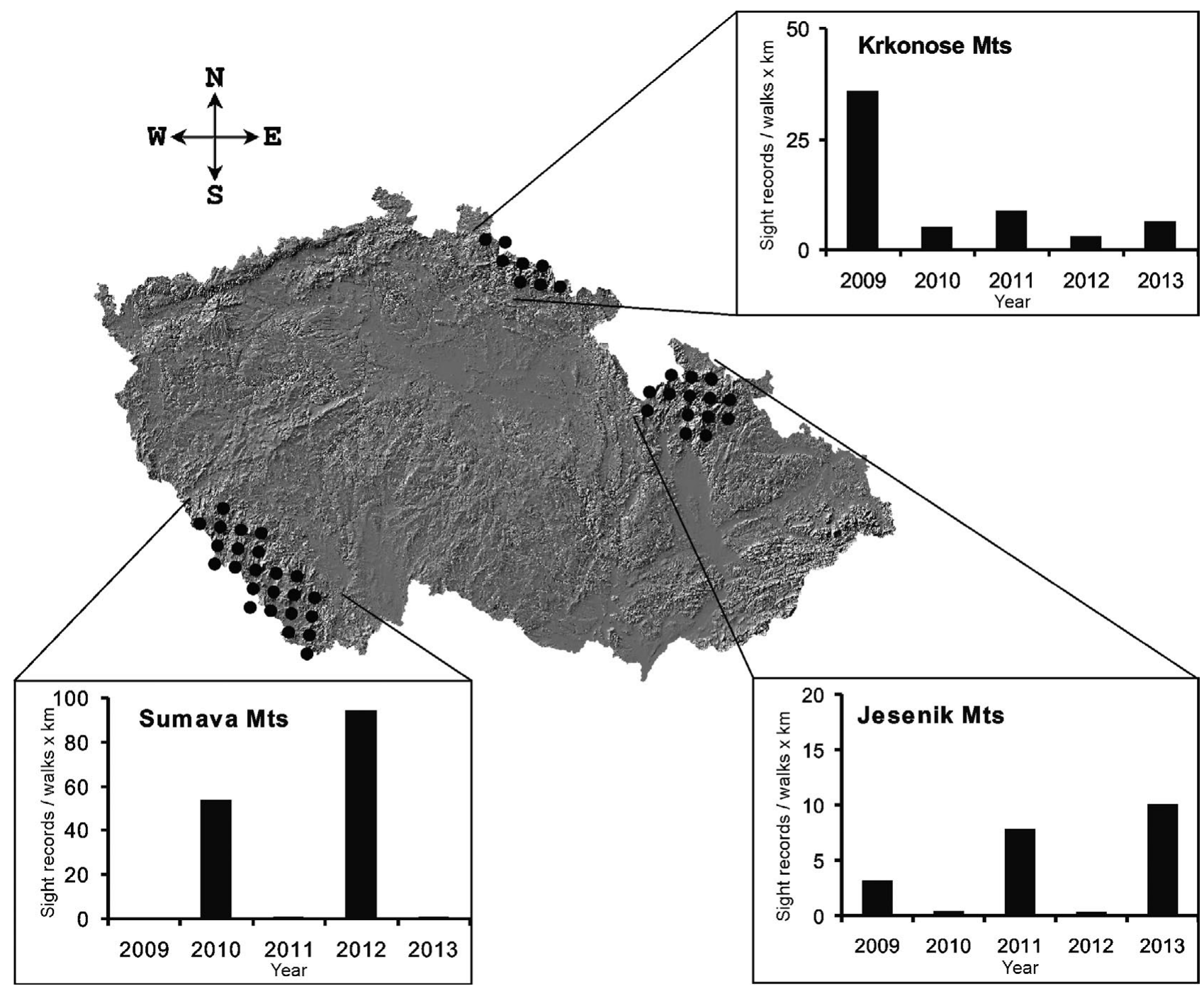

Fig. 1. Map of the recent (post-2002) distribution of Erebia euryale in the Czech Republic, expressed in terms of the grid cells used for Czech Butterfly Recording (Benes et al., 2002) occupied by E. euryale (black dots), with three diagrams showing the numbers of E. euryale recorded in 2009-2013 along fixed transects in the three main mountain ranges (standardized in terms of the annual number of transect walks and transect length). Note the different scales of the vertical axes of the diagrams.

pine zone relatives. A biennial life cycle has been reported in the Alps (Wipking \& Mengelkoch, 1994; Sonderegger, 2005) and High Tatra Mts (Slaby, 1947). No similarly detailed information exists for the lower altitude mountain ranges in Central Europe.

\section{MATERIAL AND METHODS}

Erebia euryale occurs in three Czech mountainous regions (Fig. 1): Šumava Mts (southwest); Jizerské Mts and Krkonoše Mts (north); and Králický Sněžník Mts, Rychlebské Mts, Hrubý Jeseník Mts and Orlické Mts (northeast) (Benes et al., 2002). Its altitudinal distribution differs in these mountain ranges and adult flight period varies with altitude, starting ca one month earlier at the lower than the upper limit of their altitudinal distributions (Cizek et al., 2003).

From 2009 onwards, we established permanent transects in each of the three main mountainous areas in the Czech Republic, specifically targeting habitats of Erebia spp. and aiming to monitor their adult numbers and phenology. The three transects were: (1) Šumava Mts: transect length 14 km, altitude range 990-
$1140 \mathrm{~m}$, entire length below the timberline. The mountains consist of a flat elevated plateaux, not reaching the timberline in the Czech part of the mountains (max altitude: Plechý/Plockenstein, $1378 \mathrm{~m}$ ) but rising above it marginally in Germany (Großer Arber, $1456 \mathrm{~m}$ ). Prevailing vegetation along this transect was Picea abies - Sorbus aucuparia mountain taiga, fragmented by clearfelled areas. (2) Krkonoše Mts: transect length $7 \mathrm{~km}$, altitude range 1050-1510 m. These mountains, the highest in the Czech Republic (Sněžka Mt, 1602 m), have a well-developed subalpine (dominated by Pinus mugo dwarf pine) and alpine (alpine grasslands) zones, with the timberline at ca $1250 \mathrm{~m}$. In these mountains observations were carried out along a transect that ascended from cultural grasslands within Picea abies - Sorbus aucuparia taiga, through the Pinus mugo belt towards alpine grasslands. (3) Hrubý Jeseník Mts: transect length $4 \mathrm{~km}$, altitude range 1320-1460 m. These mountains are similar to the Krkonoše in many aspects, except for the absence of a Pinus mugo zone (the timberline is formed by clumps of Picea abies) and the timberline slightly higher, at ca $1300 \mathrm{~m}$ alt. In these mountain observations were carried out along a transect that ascended from the timberline towards alpine grasslands. 
TABLE 1. Overview of the data collected during 5-years' monitoring of the butterfly Erebia euryale in the Šumava, Krkonoše and Hrubý Jeseník Mts in the Czech Republic. The numbers of transect walks and sightings are summed per year. The day of first appearance, maximum number observed and the last record (vii - July, viii - August) roughly indicate the beginning, peak and termination of the adult flight periods.

\begin{tabular}{|c|c|c|c|c|c|c|}
\hline \multirow{2}{*}{ Mountains } & \multirow{2}{*}{ Year } & \multirow{2}{*}{ No. of walks } & \multirow{2}{*}{ No. of sightings } & \multicolumn{3}{|c|}{ Flight period } \\
\hline & & & & Beginning & Maximum & Last record \\
\hline \multirow[t]{5}{*}{ Šumava } & $2009^{*}$ & 5 & 13 & 16. vii. & 26. vii. & 26. vii. \\
\hline & 2010 & 22 & 16462 & 8. vii. & 22. vii. & 14. viii. \\
\hline & 2011 & 18 & 93 & 9. vii. & 16. vii. & 11. viii. \\
\hline & 2012 & 19 & 25027 & 5. vii. & 27. vii. & 15. viii. \\
\hline & 2013 & 14 & 59 & 16. vii. & 3. vii. & 7. viii. \\
\hline \multirow[t]{4}{*}{ Krkonoše } & 2009* & 7 & 1754 & 12. vii. & 22. vii. & 23. vii. \\
\hline & 2010 & 23 & 789 & 3. vii. & 21. vii. & 12. viii. \\
\hline & 2011 & 25 & 1521 & 5. vii. & 13. vii. & 12. viii. \\
\hline & 2012 & 24 & 487 & 1. vii. & 26. vii. & 12. viii. \\
\hline \multirow[t]{6}{*}{ Jeseník } & 2013 & 19 & 821 & 2. vii. & 26. vii. & 10. viii. \\
\hline & $2009 *$ & 5 & 61 & 14. vii. & 22. vii. & 23. vii. \\
\hline & 2010 & 18 & 24 & 21. vii. & 2. viii. & 12. viii. \\
\hline & 2011 & 22 & 679 & 7. vii. & 29. vii. & 14. viii. \\
\hline & 2012 & 19 & 14 & 23. vii. & 4. viii. & 10. viii. \\
\hline & 2013 & 18 & 720 & 18. vii. & 3. viii. & 11. viii. \\
\hline
\end{tabular}

* In 2009, the monitoring terminated two weeks earlier than in the subsequent years.

These transects were walked along by volunteer biology students, trained to distinguish the target butterflies. Following the method of Pollard \& Yates (1993), students walked along transects when weather conditions were appropriate and counted all the individuals seen in ca $5 \mathrm{~m}$ cubes in front of them. Targeting only a specific set of species, transects were walked from the beginning of July to mid-August, except in 2009 when recording terminated at the end of July. By walking transects daily more detailed information on changes in seasonal abundance were obtained than by standard transect monitoring schemes.

To compare the numbers of $E$. euryale recorded annually along the three transects over the five year period of this study, we summed the daily records from each transect and year, and standardized them by dividing this annual sum by the number of transect walks in that year and the transect length (in $\mathrm{km}$ ). In this way, we obtained a standardized yearly index of the average number of butterflies seen along each kilometre of transect per day. As the period of observation spanned most of the species' flight season, this index should be robust enough to not be affected by seasonal variation in the daily records. Next, we computed, separately for each transect, a generalised linear model relating the yearly index to even (i.e. those years terminating with an even numeral: 2010, 2012) versus odd (terminating with an odd numeral: 2009, 2011, 2013) years. The presence/absence of biennial fluctuation in the records for particular transects and differences in the fluctuations among transects were tested using generalised linear models in programme R v. 2.15.2 (R Development Core Team, 2011). We used year as a two-level (even, odd) predictor and the yearly in$d e x$ as the response variable (quasipoisson distribution). First, we tested the occurrence of fluctuations in the records for each transect separately. Second, we investigated if there were differences in the biennial patterns in the records for the different transects. We used transect as a three-level predictor (Hrubý Jeseník, Krkonoše, Šumava) and compared the model containing its interaction with year (yearly index $\sim$ year + transect + year*transect) with the model not containing it (yearly index $\sim$ year + transect).

To assess the effect of weather on adult abundance, we regressed, separately for each transect, the yearly index against average July and August temperatures and precipitation. To compare the effects of weather across the three transects, we added the weather predictors to the above model, which compared transects and contained the year*transect interaction. Weather data was obtained from the Czech Hydrometeorological Institute (http:// www.chmi.cz) for the Olomouc (Jeseník Mts), Hradec Kralové (Krkonoše Mts) and South Bohemian Regions (Šumava Mts).

\section{RESULTS}

For the Šumava Mts transect, a total of 41,654 E. euryale were observed during 78 walks; for the Krkonoše Mts transect, 5,372 during 98 walks and for the Hrubý Jeseník Mts transect, 1498 during 82 walks. From Table 1, it is apparent that the beginnings of flight season varied by several weeks, usually starting at the end of the first or during the second week of July. In years when the abundance of $E$. euryale was low, the earliest individuals were recorded as late as the end of the third week of July. The periods in which the maximum butterfly abundance were recorded also differed among years and transects. The interval between the beginning of the flight season and when the maximum abundance was recorded varied from one to three weeks. Because the maximum sightings were recorded close to the termination of monitoring in 2009 (end of July), we prolonged the monitoring until mid-August in the following years. The time suitable for butterfly activity was restricted by weather, with every year only about half of the 30-45 days covered by the monitoring period suitable for butterfly activity. In 2009, due to an extremely rainy July, only one week was suitable for butterfly activity.

Biennial fluctuations were most prominent in the records for the Šumava Mts transect, along which E. euryale was most abundant in even years (null model deviance: 280.97; fitted deviance: $269.39 ;$ d.f. $=1,3 ; P<0.0001)$. There were no fluctuations in the records for the Krkonoše Mts transect 
(null model deviance: 50.51; fitted deviance: 19.93; d.f. $=$ $1,3 ; P=0.269)$. In the records for the Hrubý Jeseník Mts transect (null deviance: 25.64; fitted deviance: 21.45 ; $d$.f. $=1,3 ; P=0.025)$ the abundance of the moth was greatest in odd years (Fig. 1). The difference among transects was further corroborated by comparing models relating yearly index to year + transect (null deviance: 469.2; fitted deviance: $283.2, F=2.19$, d.f. $=3,11, P=0.146$ ), with a model containing the transect $*$ year interaction (fitted deviance: 46.36; comparison with null model: $F=15.93$, d.f. $=5,9$, $P<0.0001)$. The latter model was a significantly better fit to the data $(F=22.31$, d.f. $=2,9, P<0.0001)$, indicating the existence of contrasting patterns in the three Czech mountain areas.

Neither temperature nor precipitation during the study period affected the abundance recorded along any of the three transects (when compared with null models, all $P>$ 0.1 ). Moreover, none of the weather variables improved the fit of the model containing the transect*year interaction (temperature: fitted deviance: $36.24, F=2.09$, d.f. $=$ 1,8, $P=0.187$; precipitation: fitted deviance: $46.24, F=$ 0.019 , d.f. $=1,8, P=0.894$ ) suggesting that the observed fluctuations in abundance were not caused directly by fluctuations in weather conditions.

\section{DISCUSSION}

Our findings provide the first quantitative evidence based on transect counts in the field of biennial fluctuations in the abundance of E. euryale in the Czech Republic. The fluctuations occur with different periodicity, and perhaps intensity, in the different mountain ranges. The abundance is greatest in even years, and the butterfly is nearly absent in odd years in the Šmava Mts in the southwestern part of the Czech Republic. It is greatest in odd years in the Jeseník Mts in the northeastern part of the Czech Republic, and the biennial fluctuations are less pronounced there. There is no biennial synchronicity in the records for the Krkonoše Mts in the northern part of the Czech Republic. Wipking \& Mengelkoch (1994) report that biennially fluctuating Erebia populations reach higher maxima than non-fluctuating populations, which agrees with our records for the Šumava Mts (distinct fluctuations). The fluctuations recorded for the Hrubý Jeseník Mts were not similarly distinct (Fig. 1). Elsewhere, higher E. euryale numbers in odd years are mentioned by Slaby (1947) for the High Tatra Mts, Slovakia and the Austrian, German and Swiss Alps (Wipking \& Mengelkoch, 1994). In the Swiss Jura Mts, Sonderegger (2005) records populations with peaks of abundance in even years, and close by, populations that did not fluctuate. Thus, the biennial pattern in the abundance of E. euryale seems to vary across the species' range.

Causes and mechanisms of these fluctuations, their different periodicity and intensity, remain unclear. We can ask two main questions. How long does it take E. euryale to complete its development in the Czech Republic and What triggers the synchronicity of the inter-year fluctuations in abundance and causes the geographic differences in their periodicity? It is frequently recorded that E. euryale takes two years to complete its development (Sonderegger, 2005), but it is possible for it to take only one year, e.g. in more favourable conditions in captivity (Sonderegger, 2005). The biennial peaks recorded in the Šmava Mts, and probably also in the Hrubý Jeseník Mts, result from synchronised two year development. The adults of E. euryale recorded in the Šumava and Hrubý Jeseník Mts in "poor years" may evade this synchronicity by taking only one year to complete their development. Alternatively, these adults may also take two years to complete their development, but are not synchronized with majority of the population, which could be tested using molecular tools (cf. Vila \& Bjorklund, 2004). Annual occurrence of E. euryale in the Krkonoše Mts may be a consequence of either more frequent one-year development, or coexistence of two alternating cohorts with two-year development. However, variation in the length of development in butterflies is affected by many environmental factors (Gotthard, 2008). Genotypes interact with environmental factors, such as temperature, photoperiod, host plant quality or population age, all of which can affect adults and/or larvae (Gotthard, 2008; Saastamoinen et al., 2013). For instance, we did not determine the effect of summer weather on adult abundance, but the length of development may also be affected by conditions experienced by overwintering larvae, such as the quantity and duration of snow cover (cf. Vrba et al., 2012). The geographic variation in the fluctuations in abundance of E. euryale recorded in this study probably represent such a complex case.

It is likely that the triggers synchronising the biennial fluctuations differ in the different mountain ranges studied and can be weakened, if they exist at all, in such areas as the Krkonoše Mts. No synchronization was recorded in the Krkonoše Mts, which have a more complex topography than the Jeseník Mts (weak synchronization) and the Sumava Mts (almost complete synchronization). Microclimatic conditions are more variable in topographically more complex areas, and indeed regional-scale variation in the fluctuations in the abundance of E. euryale are reported in the Swiss Jura Mts, a topographically rugged karstic region (Sonderegger, 2005). Although much more work, such as monitoring across entire mountain ranges, would be necessary to confirm this, we propose the following working hypothesis: rugged terrain desynchronizes and flat terrain synchronizes the time it takes E. euryale to complete its development.

What other factors synchronize biennial fluctuations? The hypothesis proposed by Wipking \& Mengelkoch (1994) states that parasitization of larvae in years when they are very abundant reduces numbers of adults the following year, thus selecting against rapidly developing individuals and favouring those developing slowly. In addition to high parasitoid pressure, the individuals that developed rapidly may fail to locate mates. However, nothing is currently known about the spectra or host specificity of parasitoids attacking E. euryale in the mountains in the Czech Republic [several Satyrinae butterflies, possible alternative 
hosts for parasitoids, coexist with E. euryale in all three mountain ranges studied (Benes et al., 2002)].

Finally, the different degrees of synchronization recorded in the mountain ranges studied may be due to the different postglacial histories of the respective populations. Each of the current Czech Republic populations might have had a different glacial refugium, the odd-year Hrubý Jeseník population possibly sharing a refugium with the odd-year populations now inhabiting the eastern Carpathian Mts (Slabý, 1947). To test this hypothesis it necessary to expand the phylogeographic studies of extant E. euryale (Schmitt \& Haubrich, 2008) to include populations from Europe north of the Alps.

The synchronized biennial development of mountain insects remains a challenging phenomenon. Documenting the spatial patterns in development that exist in populations of E. euryale is a necessary first step for studies on the underlying mechanisms, focusing on the populations' history, interactions with parasitoids and effects of climate change (cf. Logan \& Powell, 2001; Hodgson et al., 2011) on biennial mountain species.

ACKNOWLEDGEMENTS. We are grateful to over 50 student volunteers who participated in the monitoring of Erebia, the administrations of Šumava National Park, Krkonoše National Park and the Jeseníky Protected Landscape Area for encouragement, logistic support and accommodation in their respective regions and to M. Sweney for linguistic corrections. I. Černá, J. Kollros and Z. Lasovský helped with coordinating the monitoring. $J$. Beneš completed the distributional data using the Czech Butterfly Recording and Nature Conservation Authority databases. Financial support came from grants from the Grant Agency of the Czech Republic (GACR P505/10/1630, P505/10/2248, P505/10/2167), University of South Bohemia (GAJU 135/2010/P, 144/2010/P, GAJU 106/2010/P) and a Motyli Krkonos contract (CZ.3.22/1.2.00/12.03299).

\section{REFERENCES}

Benes J., Konvicka M., Dvorak J., Fric Z., Havelda Z., Pavlicko A., Vrabec V. \& Weidenhoffer Z. (eds) 2002: [Butterflies of the Czech Republic: Distribution and Conservation] I., II. SOM, Prague, 857 pp. [in Czech, English abstracts].

Cizek O., Bakesova A., Kuras T., Benes J. \& Konvicka M. 2003: Vacant niche in alpine habitat: the case of an introduced population of the butterfly Erebia epiphron in the Krkonose Mountains. - Acta Oecol. 24: 15-23.

Dennis R.L.H, Hodgson J.G., Grenyer R., Shreeve T.G. \& Roy D.B. 2004: Host plants and butterfly biology. Do host-plant strategies drive butterfly status? - Ecol. Entomol. 29: 12-26.

DouwES P. 1980: Periodical appearance of species of the butterfly genera Oeneis and Erebia in Fennoscandia (Lepidoptera, Satyridae). - Entomol. Gener. 6: 151-157.

Douwes P. \& Stille B.O. 1988: Selective versus stochastic processes in the genetic differentiation of populations of the butterfly Erebia embla (Thnbg) (Lepidoptera, Satyridae). - Hereditas 109: 37-43.

Gilg O., Sittler B., Sabard B., Hurstel A., Sane R., Delattre P. \& HANSKI I. 2006: Functional and numerical responses of four lemming predators in high arctic Greenland. _ Oikos 113: 193-216.

GotThARD K. 2008: Adaptive growth decisions in butterflies. BioScience 58: 222-230.
Hodgson J.A., Thomas C.D., Oliver T.H., Anderson B.J., BRERETON T.M. \& CRONE E.E. 2011: Predicting insect phenology across space and time. - Glob. Change Biol. 17: 1289-1300.

Konvicka M., Benes J. \& Kuras T. 2002: Microdistribution and diurnal behaviour of two sympatric mountainous butterflies (Erebia epiphron and E. euryale): relations to vegetation and weather. - Biologia 57: 221-233.

Kudrna O., Harpke A., Lux K., Pennerstorfer J., Schweiger O., Settele J. \& Wiemers M. 2011: Distribution Atlas of Butterflies in Europe. 2nd ed. Gesellschaft für Schmetterlingsschutze e.V., Halle, $576 \mathrm{pp}$.

Kukal O. \& Kevan P.G. 1987: The influence of parasitism on the life history of a high arctic insect, Gynaephora groenlandica (Wöcke) (Lepidoptera: Lymantriidae). - Can. J. Zool. 65: 156-163.

Logan J.A. \& Powell J.A. 2001: Ghost forests, global warming and the mountain pine beetle. - Am. Entomol. 47: 160-173.

MikKola K. \& KononenKo V.S. 1989: Flight year of alternateyear Xestia moths (Lepidoptera: Noctuidae) in north-eastern Siberia - A character from the Ice Ages. - Nota Lepid. 12: 144-152.

Pollard P. \& Yates T.J. 1993: Monitoring Butterflies for Ecology and Conservation: The British Butterfly Monitoring Scheme. 1st ed. Chapman \& Hall, London, 292 pp.

R Development Core Team 2011: $R$ : A Language and Environment for Statistical Computing. R Foundation for Statistical Computing, Vienna, URL http://www.R-project.org/.

Roos P. \& ArnscheID W. 1981: Eine interessante Zucht und die Praimaginalstadien von Erebia manto Schiffermuller, 1775 (Lepidoptera, Satyridae) (Beitrage zur Kenntnis der Erebien, XIV). - Nachrittenbl. Bayer. Entomol 6: 101-108.

SaAstamoinen M., Ikonen S., Wong S.C., Lehtonen R. \& Hanski I. 2013: Plastic larval development in a butterfly has complex environmental and genetic causes and consequences for population dynamics. - J. Anim. Ecol. 82: 529-539.

Settele J., Dover J., Konvicka M. \& Dolek M. 2009: Butterflies of European ecosystems: impact of land use and options for conservation management. In Settele J., Shreeve T., Konvicka M. \& van Dyck H. (eds): The Ecology of Butterflies in Europe. CUP, Cambridge, pp. 353-370.

Schmitt T. \& Haubrich K. 2008: The genetic structure of the mountain forest butterfly Erebia euryale unravels the late Pleistocene and postglacial history of the mountain coniferous forest biome in Europe. - Mol. Ecol. 17: 2194-2207.

Schmitt T., Hewitt G.M. \& Muller P. 2006: Disjunct distributions during glacial and interglacial periods in mountain butterflies: Erebia epiphron as an example. - J. Evol. Biol. 19: 108-113.

Sonderegger P. 2005: Die Erebien der Schweiz (Lepidoptera: Satyrinae, Genus Erebia). Private publication, W. Gassmann, Biel, Switzerland, $712+73$ pp.

Slaby O. 1947: Zastupci rodu Erebia Dalm. ve Vysokych Tatrach. Les espèces du genre Erebia Dalm. dans les Hautes Tatras. - Acta Soc. Entomol. Bohem. 44: 102-119 [in Czech, French abstr.].

VAlLe K.J. 1933: Die Lepidopterenfauna des Petsamogebiets. Ann. Zool. Soc. Zool.-Bot. Fenn. Vanamo 1: 1-262.

VARKonyi G., Hanski I., Rost M. \& ItAmies J. 2002: Host-parasitoid dynamics in periodic boreal moths. - Oikos 98: 421-430.

VILA M. \& BJorkLund M. 2004: Testing biennialism in the butterfly (Nymphalidae: Satyrinae) by mtDNA sequencing Erebia palarica. - Insect Mol. Biol. 13: 213-217.

Vrba P., Konvicka M. \& Nedved O. 2012: Reverse altitudinal cline in cold hardiness among Erebia butterflies. - CryoLetters 33: 251-258. 
WARren B.C.S. 1936: Monograph of the Genus Erebia. Adlard and Son, London, $407+104 \mathrm{pp}$.

Wipking W. \& MengelKoch C. 1994: Control of alternate-year flight activities in high-alpine Ringlet Butterflies (Erebia, Satyridae) and Burnet moths (Zygaena, Zygaenidae) from temperate environments. In Danks H.V. (eds): Insect Life-Cycle Poly- morphism: Theory, Evolution and Ecological Consequences for Seasonality and Diapause Control. Kluwer Academic Publisher, Dordrecht, pp. 313-347.

Received January 13, 2014; revised and accepted June 16, 2014 Prepublished online October 16, 2014 